\title{
PENDEKATAN SAINTIFIK UNTUK MENINGKATKAN AKTIVITAS DAN HASIL BELAJAR IPA SISWA SMP
}

\author{
Irdam Idrus ${ }^{1 *}$, Irwandi Ansori ${ }^{1}$, Rio Kurniawan \\ ${ }^{1}$ Program Studi Pendidikan Biologi, Fakultas Keguruan dan Ilmu Pendidikan, Universitas Bengkulu \\ ${ }^{2}$ Program Studi Pendidikan Bahasa dan Sastra Indonesia, Fakultas Keguruan dan Ilmu Pendidikan \\ Universitas Bengkulu \\ Email : iidrus@unib.ac.id
}

\begin{abstract}
Abstrak
Penelitian ini bertujuan untuk mendeskripsikan aktivitas belajar dan meningkatkan hasil belajar siswa kelas VII SMP 1 Kota Bengkulu dengan menerapkan pendekatan saintifik. Jenis penelitian ini adalah penelitian tindakan kelas dengan metode deskriptif, penelitian terdiri dari dua siklus dengan setiap siklusnya terdiri atas tahap perencanaan, pelaksanaan tindakan, observasi, dan refleksi. Subyek penelitian adalah satu orang guru IPA dan 32 orang siswa kelas VIIA SMPN 1 Kota Bengkulu. Teknik pengumpulan data dilakukan dengan observasi dan tes. Dari hasil observasi yang dilakukan, aktivitas pembelajaran dengan menggunakan pendekatan saintifik telah terlaksana dengan baik. Data hasil belajar menunjukkan peningkatan dari siklus I ke siklus II. Pada siklus I persentase ketuntasan klasikal yang diperoleh sebesar $43,75 \%$ dan pada siklus II meningkat menjadi $78,13 \%$. Pada sikus II hasil belajar yang diperoleh telah mencapai ketuntasan belajar klasikal mata pelajaran IPA di SMPN 1 Kota Bengkulu. Dari hasil penelitian dapat disimpulkan bahwa pembelajaran IPA di SMPN 1 Kota Bengkulu dapat meningkatkan aktivitas belajar dan hasil belajar IPA siswa SMP
\end{abstract}

Kata Kunci: Pendekatan Saintifik, Aktivitas Belajar IPA, Hasil Belajar IPA

\begin{abstract}
This study aims to describe the learning activities and improve the learning outcomes of the VII grade students of SMP 1 Bengkulu City by applying a scientific approach. This type of research is a classroom action research with descriptive method, the research consists of two cycles with each cycle consisting of the stages of planning, implementing the action, observing, and reflecting. The research subjects were one science teacher and 32 class VIIA students at SMPN 1 Bengkulu City. Data collection techniques were carried out by observation and tests. From the results of observations made, learning activities using a scientific approach have been carried out well. The learning outcome data shows an increase from cycle I to cycle II. In the first cycle the percentage of classical completeness obtained was $43.75 \%$ and in the second cycle increased to $78.13 \%$. In cycle II the learning outcomes obtained have reached classical learning completeness in science subjects at SMPN 1 Bengkulu City. From the results of the study it can be concluded that learning science at SMPN 1 Bengkulu City can increase learning activities and science learning outcomes of junior high school students.
\end{abstract}

Keywords: Scientific Approach, Science Learning Activities, Science Learning Outcomes 


\section{PENDAHULUAN}

Menurut Depdiknas (2007) pembelajaran IPA mempunyai tujuan agar siswa memiliki kemampuan yakni: (1) memperoleh keyakinan terhadap kebesaran Tuhan Yang Maha Esa berdasarkan keberadaan, keindahan dan keteraturan alam ciptaan-Nya; (2) mengembangkan pengetahuan dan pemahaman konsep-konsep IPA yang bermanfaat dan dapat diterapkan dalam kehidupan sehari-hari; mengembangkan rasa ingin tahu, sikap positif dan kesadaran tentang adanya hubungan yang saling mempengaruhi antara IPA, lingkungan, teknologi dan masyarakat; (4) mengembangkan keterampilan proses untuk menyelidiki alam sekitar, memecahkan masalah dan membuat keputusan; (5) meningkatkan kesadaran untuk berperan serta dalam memelihara, menjaga dan melestarikan lingkungan alam; (6) meningkatkan kesadaran untuk menghargai alam dan segala keteraturannya sebagai salah satu ciptaan Tuhan, dan (7) memperoleh bekal pengetahuan, konsep dan keterampilan IPA sebagai dasar untuk melanjutkan pendidikan ke jenjang yang lebih tinggi.

Pendidikan pada hakikatnya harus memperhatikan karakteristik siswa, perkembangan mental anak pada masa operasional konkret, pada dasarnya siswa belajar melalui objek yang konkret (Samatoa, 2006). Guru harus dapat menerapkan pendekatan pembelajaran yang sesuai dengan kebutuhan dan karakteristik siswanya. Untuk mencapai tujuan tersebut, siswa harus belajar cara berinteraksi dengan lingkungan belajar yang kondusif yang diciptakan guru dalam pembelajaran yang mencakup tujuan pembelajaran, pendekatan pembelajaran, dan penilaian evaluasi belajar. Keberhasilan pembelajaran IPA bergantung dari siswa dan guru itu sendiri jika pembelajaran ditunjang oleh sarana dan prasarana pendidikan yang memadai, minat serta keinginan siswa yang besar untuk belajar maka keberhasilan itu tentunya akan mudah untuk didapatkan.

Berdasarkan hasil pengamatan dalam pembelajaran IPA di kelas VII SMPN 1 Kota Bengkulu diperoleh permasalahan terhadap pembelajaran IPA antara lain sebagai berikut: 1) pendekatan yang digunakan kurang bervariasi sehingga pembelajaran masih berpusat hanya pada guru; 2) guru kurang melibatkan siswa dalam proses pembelajaran sehingga siswa pasif dan motivasi belajar siswa rendah; 3) penggunaan media dan alat-alat konkrit dalam pembelajaran jarang dilakukan; 4) guru kurang memberi penghargaan kepada siswa baik secara verbal maupun non verbal; 5) saat diberikan evaluasi siswa sering mengalami kesalahan dalam menyelesaikan soal pembelajaran sehingga hasil belajar siswa masih rendah belum mencapai ketuntasan belajar secara klasikal. Menurut Wahyono (2017) dalam penelitiannya bahwasanya dalam pembelajaran, guru harus mampu mengembangkan pembelajaran dengan melaksanakan program yang telah disiapkan, oleh sebab itu diharapkan guru memiliki kemampuan untuk, memperjelas tujuan pembelajaran, membangkitkan minat siswa, dan menciptakan lingkungan belajar yang menyenangkan.

Dari uraian tersebut, maka pembelajaran yang dilaksanakan selama ini cenderung kurang melibatkan siswa di dalamnya sehingga siswa kurang memahami konsep-konsep IPA dan hasil belajar siswa pun kurang memuaskan. Untuk menindaklanjuti permasalahan di atas, guru harus mencari alternatif pembelajaran yang menarik minat belajar 
siswa agar lebih aktif dan kreatif yakni melalui penerapan pendekatan saintifik. $\mathrm{Hal}$ ini dimaksudkan agar tujuan pembelajaran yang diharapkan dapat tercapai sehingga aktivitas dan hasil belajar siswa juga meningkat. Penelitian ini bertujuan untuk meningkatkan aktivitas dan hasil belajar IPA materi alat indera di kelas VII SMP Negeri 01 Kota Bengkulu melalui pendekatan saintifik.

\section{METODE}

Penelitian ini merupakan Penelitian Tindakan Kelas (PTK) yang menggunakan metode deskriptif kualitatif (Arikunto, 2010). Subyek penelitian adalah satu orang guru IPA dan 32 orang siswa kelas VIIA SMPN 1 Kota Bengkulu. Teknik pengumpulan data yang digunakan dalam penelitian ini adalah observasi dan tes, dengan menggunakan ilnstrumen berupa lembar observasi dan lembar tes.

Lembar observasi digunakan untuk melihat aktivitas mengajar guru dan aktivitas belajar siswa. Lembar observasi dikembangkan berdasarkan indikator pendekatan saintifik, yang dalam instrumen penilaiannya diukur dengan Data hasil observasi dianalisis dengan menghitung rerata skor yang diperoleh dan menentukan kriterianya. Lembar tes digunakan untuk mengukur hasil belajar siswa yang belajar dengan pendekatan saintifik. Lembar observasi disusun dengan menggunakan skala penilaian dengan rentang 1-4 yaitu kurang, cukup, baik, dan sangat baik. Tes hasil belajar terdiri dari 5 soal essay. Lembar observasi dan lembar tes yang digunakan telah divalidasi oleh ahli menggunakan validasi logis. Data hasil belajar dihitung dengan menggunakan penilaian ketuntasan klasikal. Penelitian ini dilakukan dalam dua kali siklus pembelajaran.

\section{HASIL DAN PEMBAHASAN}

Dari hasil penelitian yang dilakukan di SMPN 1 Kota Bengkulu menggunakan pendekatan saintifik di kelas VIIA didapatkan hasil bahwa hampir seluruh aspek aktivitas pembelajaran dinilai baik oleh pengamat. Aspek-aspek tersebut yaitu: (1) Guru sudah baik dalam memberikan salam berdo'a dan mengecek kehadiran peserta didik. Terlihat guru memberikan salam dengan ramah dan santun sehingga membangkitkan semangat siswa untuk memulai pembelajaran melalui kegiatan absensi dan berdo'a bersama; (2) Guru sudah baik dalam membagikan LDS kepada siswa. Terlihat guru membagikan LDS secara menyeluruh kepada semua kelompok melalui perwakilan dari setiap ketua atau anggota maju ke depan kelas mengambil LDS; (3) Guru sudah baik dalam membimbing siswa berdiskusi. Terlihat guru membimbing seluruh anggota dalam kelompok secara merata dengan baik; (4) Guru sudah baik dalam memberikan evaluasi. Terlihat guru memberikan evaluasi dengan memberikan pengarahan terlebih dahulu tentang tata cara pelaksanaan tes; (5) Guru sudah baik dalam menutup pembelajaran. Terlihat guru menutup pembelajaran dengan memberikan salam, berdo'a dan memberikan pesan kesan yang baik kepada siswa.

Aspek yang dinilai masuk ke dalam kategori cukup sehingga perlu diperbaiki pada pertemuan selanjutnya di siklus II adalah (1) Guru sudah cukup baik dalam menyampaikan tujuan pembelajaran yang ingin dicapai; (2) Guru sudah cukup baik dalam meminta siswa mengamati bagianbagian telinga melalui media poster/gambar; (3) Guru sudah cukup baik dalam bertanya jawab dengan siswa; (4) Guru sudah cukup baik dalam membagi siswa ke dalam kelompok belajar; (5) Guru sudah cukup baik dalam meminta siswa 
mempresentasikan dan menyimpulkan hasil diskusi; (6) Guru sudah cukup baik dalam memberikan penghargaan kepada kelompok yang mendapat nilai terbaik; dan (7) Dengan bimbingan guru, siswa memberi kesimpulan/ rangkuman hasil belajar.

Sedangkan aspek belajar yang termasuk ke dalam kategori kurang sehingga perlu diperbaiki pada pertemuan selanjutnya di siklus II yakni: (1) Guru kurang memberikan apersepsi kepada siswa; (2) Guru kurang mendorong keberanian siswa dalam menjawab pertanyaan; dan (3) Guru kurang memberi penjelasan mengenai langkah kegiatan diskusi yang akan dilaksanakan. Pemberian pertanyaan dapat dilakukan pada saat kegiatan merumuskan masalah, hal ini berperan dalam pelibatan peserta didik ke dalam konsep pembelajaran. Menurut Trianto (2014) tahapan perumusan masalah dalam kegiatan pembelajaran melalui pemberian pertanyaan yang dapat memotivasi siswa untuk belajar berpengaruh terhadap hasil belajar siswa.

Hasil belajar siswa pada pembelajaran IPA dengan menerapkan pendekatan saintifik yang dinilai yakni nilai LDS dan tes. Nilai LDS diperoleh ratarata yakni 64,38 dengan presentase ketuntasan kelompok sebesar $50 \%$. Sedangkan penilaian tes yang dilakukan di akhir pembelajaran dengan jumlah soal 3 butir berbentuk essay. Dari 32 siswa yang mengikuti tes diperoleh nilai rata-rata kelas yakni 62,81 dengan ketuntasan belajar sebesar $53,13 \%$. Hasil tes tersebut dianalisis dengan mencari nilai rata-rata kelas dan kriteria ketuntasan belajar klasikal.

Nilai LDS dan tes tersebut digabungkan untuk melihat sebatas mana kemampuan siswa dalam menerima pembelajaran yang diberikan. Hasil belajar siswa didapatkan dari $30 \%$ nilai LDS dan
70\% nilai tes. Rekapitulasi hasil belajar siswa disajikan pada Tabel 1.

Tabel 1. Rekapitulasi Hasil Belajar Siswa Siklus I

\begin{tabular}{lc}
\hline Jumlah seluruh siswa & $\mathbf{3 2}$ \\
\hline $\begin{array}{l}\text { Jumlah siswa yang mengikuti } \\
\text { pembelajaran }\end{array}$ & 32 \\
$\begin{array}{l}\text { Jumlah siswa yang tuntas belajar } \\
\text { Jumlah siswa yang tidak tuntas }\end{array}$ & 14 \\
belajar & 18 \\
$\begin{array}{l}\text { Nilai rata-rata kelas } \\
\text { Persentase ketuntasan belajar } \\
\text { klasikal }\end{array}$ & 63,28 \\
\hline
\end{tabular}

Berdasarkan Tabel di atas terlihat bahwa hasil belajar pada siklus I belum tuntas, hal ini dikarenakan siswa belum mencapai standar ketuntasan yang ditetapkan oleh SMPN 1 Kota Bengkulu yaitu minimal $60 \%$ siswa mendapatkan nilai $\geq 70$. Data yang diperoleh dari tabel di atas bahwa rata-rata keberhasilan pembelajaran siswa yakni 63,28 dengan ketuntasan klasikal sebesar $43,75 \%$ Belum tuntasnya pembelajaran pada siklus I disebabkan karena proses pembelajaran dengan penerapan pendekatan saintifik belum terlaksana dengan optimal. Maka dari itu perlu dilakukan perbaikan di siklus II.

Pada siklus II dilakukan perbaikan aktivitas pembelajaran, hampir seluruh aspek pembelajaran telah terlaksana dengan baik. Pada siklus II ini dilakukan perbaikan proses pembelajaran yang masih termasuk ke dalam kategori cukup dan kurang pada siklus I. Berdasarkan hasil refleksi analisis data observasi siswa pada siklus II masih terdapat satu aspek yang masuk ke dalam kategori kurang baik, yaitu guru kurang dalam memberi penjelasan mengenai langkah kegiatan diskusi yang akan dilaksanakan. Berdasarkan hasil analisis data terdapat peningkatan hasil belajar siswa pada siklus II. Rekapitulasi hasil belajar siswa siklus II dapat dilihat pada Tabel 2. 
Tabel 2. Rekapitulasi Hasil Belajar Siswa Siklus II

\begin{tabular}{|c|c|}
\hline Jumlah seluruh siswa & 32 \\
\hline $\begin{array}{l}\text { Jumlah siswa yang mengikuti } \\
\text { pembelajaran }\end{array}$ & 32 \\
\hline $\begin{array}{l}\text { Jumlah siswa yang tuntas } \\
\text { belajar }\end{array}$ & 25 \\
\hline $\begin{array}{l}\text { Jumlah siswa yang tidak } \\
\text { tuntas belajar }\end{array}$ & 7 \\
\hline Nilai rata-rata kelas & 71,77 \\
\hline $\begin{array}{l}\text { Persentase ketuntasan } \\
\text { belajar klasikal }\end{array}$ & $78,13 \%$ \\
\hline
\end{tabular}

Berdasarkan Tabel di atas terlihat bahwa hasil belajar pada siklus II sudah dinyatakan tuntas dan telah mencapai standar ketuntasan belajar yang ditetapkan oleh SMP Negeri 1 Kota Bengkulu yaitu minimal $70 \%$ siswa mendapatkan nilai $\geq 70$. Data yang diperoleh yakni rata-rata hasil belajar siswa yakni 71,77 dengan ketuntasan klasikal sebesar $78,13 \%$. Peningkatan hasil belajar pada siklus II ini disebabkan karena perbaikan proses pembelajaran pada siklus II.

Aktivitas guru dan siswa yang ditunjukkan dari hasil pengamatan yang dilakukan selama proses pembelajaran dari siklus I hingga siklus II terjadi peningkatan yang baik. $\mathrm{Hal}$ ini menunjukkan bahwa ada pengaruh positif dari pendekatan saintifik terhadap aktivitas proses pembelajaran IPA di Kelas VIIA SMPN 1 Kota Bengkulu. Hal ini sesuai dengan pendapat Rohmawati dkk (2018) dan Susilo (2016) yang menyatakan bahwa pembelajaran IPA yang dilakukan dengan menggunakan pendekatan saintifik dapat terlaksana dengan baik, dimana guru telah menerapkan keterampilan $5 \mathrm{M}$ yaitu mengamati, menanya, mencoba, menalar, dan mengkomunikasikan sehingga dapat membuat siswa aktif dalam kegiatan pembelajaran. Pada siklus I rata-rata hasil belajar siswa adalah 63,28 dengan ketuntasan belajar sebesar 43,75\%.
Selanjutnya hasil belajar siswa berhasil ditingkatkan dengan baik pada siklus II dengan nilai rata-rata 71,77 dan ketuntasan belajar klasikal sebesar $78,13 \%$. Adanya peningkatan hasil belajar siswa dikarenakan adanya pengalaman pembelajaran yang dilakukan dengan menggunakan pendekatan saintifik. Hal ini sesuai dengan penyataan Winarni (2009) bahwa hasil belajar merupakan kemampuan-kemampuan yang dimiliki seseorang setelah menerima pengalaman belajar dan terjadi perubahan tingkah laku pada orang tersebut, misalnya dari tidak tahu menjadi tahu, dan dari tidak mengerti menjadi mengerti.

Oleh karena itulah hasil belajar siswa di kelas VIIA SMPN 1 Kota Bengkulu mengalami peningkatan yang baik sebab siswa ingin belajar dan bersemangat memahami pembelajaran yang disampaikan melalui pendekatan saintifik. $\mathrm{Hal}$ tersebut juga sejalan dengan pendapat Arifin (2012) yang menyatakan bahwa hasil belajar sangat dipengaruhi oleh merupakan tindakan guru dalam melakukan aktivitas belajar di dalam kelas. Salah satu tindakan guru yang dilakukan dalam kegiatan pembelajaran dengan pendekatan saintifik ini adalah memberikan pertanyaan kepada siswa baik pada saat apersepsi maupun pada saat diskusi. Hal ini sesuai dengan hasil penelitian yang dilakukan oleh Astiti dkk (2015) yang menyatakan bahwa pemberian pertanyaan oleh guru dalam pembelajaran yang menerapkan pendekatan saintifik berpengaruh terhadap hasil belajar siswa. Adanya peningkatan aktivitas dan hasil belajar IPA pada siswa di SMP 1 Kota Bengkulu didukung oleh hasil penelitian yang dilakukan oleh Harnanik (2014) bahwa penerapan pendekatan saintifik dapat meningkatkan kreativitas dan hasil belajar siswa SMP. 


\section{PENUTUP}

\section{Simpulan}

Simpulan hasil penelitian ini adalah:

1) Penerapan pendekatan saintifik di kelas VIIIA SMP Negeri 1 Kota Bengkulu dapat meningkatkan aktivitas guru dan siswa.

2) Penerapan pendekatan saintifik di kelas VIIIA SMP Negeri 1 Kota Bengkulu dapat meningkatkan hasil belajar siswa untuk mencapai kriteria tuntas secara klasikal. Nilai ketuntasan klasikal pada siklus I adalah $43,75 \%$ dan pada siklus II meningkat menjadi $78,13 \%$.

3) Dari hasil temuan penelitian, disimpulkan bahwa penggunaan pendekatan saintifik hendaknya dilengkapi dengan penggunaan model pembelajaran yang relevan dengan pendekatan tersebut.

\section{Saran}

Saran yang dapat diberikan dari hasil penelitian yang telah dilakukan, yaitu pendekatan saintifik bisa diterapkan untuk meningkatan variabel penelitian lain seperti keterampilan memecahkan masalah atau keterampilan berpikir kritis.

\section{DAFTAR PUSTAKA}

Arifin, Zainal. 2012. Evaluasi Pembelajaran. Bandung: PT Remaja Rosdakarya .

Arikunto, S. 2010. Penelitian Tindakan Kelas. Jakarta: Bumi Aksara

Astiti, Km. A., Suardika R. W., Ardana, I.Kt. 2015. Pengaruh Pendekatan Saintifik Terhadap Hasil Belajar Pengetahuan IPA Tema Tempat Tinggalku Pada Siswa Kelas VI Ditinjau dari Karakteristik Pertanyaan Guru di SD Gugus Budi Utomo. E-Journal PGSD Universitas
Pendidikan Ganesha Jurusan PGSD, 3 (1) .

Depdiknas. 2006. Standar Kompetensi Lulusan dan Standar Isi Lulusan Mata Pelajaran IPA SMP/MTs. Jakarta: Departemen Pendidikan dan Kebudayaan.

Harnanik. 2018. Pendekatan Pembelajaran Saintifik Untuk Meningkatkan Kreativitas Dan Hasil Belajar Materi Kegiatan Produksi Pada Siswa Kelas Vii D Smpn 1 Winong. Jurnal Pendidikan Ekonomi Dinamika Pendidikan, 9 (2): 115-120

Rohmawati S., Sihkabuden., \& Susilaningsih. 2018. Penerapan Pendekatan Saintifik Pada Mata Pelajaran IPA di MTS Putri Nurul Masyithoh Lumajang. JKTP, 1 (3): 205-2012.

Samatowa, U. 2006. Bagaimana Membelajarkan IPA di Sekolah Dasar. Jakarta: Depdiknas

Susilo, M.J. 2016. Pembelajaran IPA Biologi Berbasis Saintifik Approach di SMP Muhammadiyah 2 Depok Sleman. Prosiding Biology Education Conference, 13 (1): 97101.

Trianto. 2014. Mendesain Model Pembelajaran Inovatif, Progresif dan Kontekstual: Konsep, Landasan, dan implementasinya pada Kurikulum 2013 (Kurikulum Tematik Integratif/KTI). Jakarta: Prenadamedia Group.

Wahyono, Abdulhak, I. \& Rusman. 2017. Implementation Of Scientific Approach Based Learning To Think High Levels In State Senior High School In Ketapang. International Journal of Education and Research, 5 (8): 221-230 
Winarni, E. Widi. 2009. Mengajar IPA

Secara Bermakna. Bengkulu: UNIB

PRESS. 